\title{
Low Leach Rate Glasses for Immobilization of Nuclear Wastes
}

\author{
L. A. Chick \\ C. Q. Buckwalter
}

October 1980

Prepared for the U.S. Department of Energy under Contract DE-AC06-76RLO 1830

Pacific Northwest Laboratory Operated for the U.S. Department of Energy by Battelle Memorial Institute 
NOTICE

This report was prepared as an account of work sponsored by the United States Covernment. Nieither the United States nor the Department of Energy. nor any of their employees. nor any of their contractors, subcontractors, or their employees. makes any warranty, express or implied, or assumes any legal liability or responsibility for the accuracy, completeness or usefulness of anv information. apparatus, product or process disclosed, or represents that its use would not infringe privately owned rights.

The views, opinions and conclusions contained in this report are those of the contractor and do not necessarily represent those of the United States Government or the United States Department of Energy.

\author{
PACIFIC NORTHWEST LABORATORY \\ operated by \\ BATTELLE \\ for the \\ UNITED STATES DEPARTMENT OF ENERGY \\ Under Contract DE-AC06-76RLO 1830
}
Printed in the United States of America Available from
National Technical Information Service
United States Department of Commerce 5285 Port Royal Road
Springfield. Virginia 22151

Price: Printed Copy S $\therefore$ Microfiche $\$ 3.00$

$\begin{array}{cc}\text { *Pages } & \begin{array}{c}\text { VTIS } \\ \text { Selling Price }\end{array} \\ & \\ 001-025 & \$ 4.00 \\ 026-050 & \$ 4.50 \\ 051-075 & \$ 5.25 \\ 076-100 & \$ 6.00 \\ 101-125 & \$ 6.50 \\ 126-150 & \$ 7.25 \\ 151-175 & \$ 8.00 \\ 176-200 & \$ 9.00 \\ 201-225 & \$ 9.25 \\ 226-250 & \$ 9.50 \\ 251-275 & \$ 10.75 \\ 276-300 & \$ 11.00\end{array}$


PNL-3522

UC -70

\section{7}

LOW LEACH RATE GLASSES FOR

IMMOBILIZATION OF NUCLEAR WASTES

L. A. Chick

C. Q. Buckwalter

October 1980

Prepared for the U.S. Department of Energy under Contract DE-ACO6-76RLO 1830

Pacif ic Northwest Laboratory

Richl and, Washington 99352 


\section{ACKNOWLEDGMENTS}

The authors wish to thank W. J. Gray for conducting the volatility investigations, and G. B. Mellinger and R. P. Sinith for conducting the studies of viscosity and hydrothermal leaching, respectively. We are grateful to G. L. McVay and R. P. Turcotte for discussions aiding in the interpretation of results. Finally, we appreciate the technical assistance of $K$. R. Weisch, B. L. Riddle, F. D. Hobbs, C. A. Church, and K. D. Richardson and the editing of S. K. Edler. 


\section{SUMMARY}

Improved defense and commercial waste glasses are shown to have about one order of magnitude lower leach rates at $90^{\circ} \mathrm{C}$ in static deionized water than corresponding reference defense and commercial waste glasses. This durability difference diminishes as the leaching temperature is raised; at $200^{\circ} \mathrm{C}$ there is no significant difference in leach rates. However, at repository temperatures less than $150^{\circ} \mathrm{C}$, the improved compositions would have considerable advantages over reference glasses, based on our tests in deionized water. The formulation changes that cause increased durability are not yet fully understood but may involve increased $\mathrm{SiO}_{2}$ as well as the presence of $\mathrm{Al}_{2} \mathrm{O}_{3}$ and $\mathrm{Fe}_{2} \mathrm{O}_{3}$ and their proportion with respect to the alkali oxides.

Melting temperatures of some of the high-durability glasses $\left(1350-1450^{\circ} \mathrm{C}\right)$ are higher than those for borosilicate glasses currently being investigated for process application $\left(1050^{\circ} \mathrm{C}\right)$. However, there is at least one high-durability glass that is compatible with extended use in existing equipment; cthers could be processed in the higher temperature equipment commoniy in use in the commercial glass industry.

As expected, at the melting temperatures necessary for most of the highdurability glasses, volatility was found to be higher than that experienced in processing current reference glasses. Higher volatilities might be compensated for by specific design of the off-gas system for improved off-gas treatment and volatile materials recovery.

It is concluded that certain waste glass formulations are significantly more durable than current reference waste glasses at temperatures of less than $150^{\circ} \mathrm{C}$ in deionized water and that, although processing of these glasses would require some changes in current nuclear waste glass processing equipment, the formulations deserve further investigation because they provide viable improvements over current reference waste glasses. 


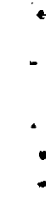




\section{CONTENTS}

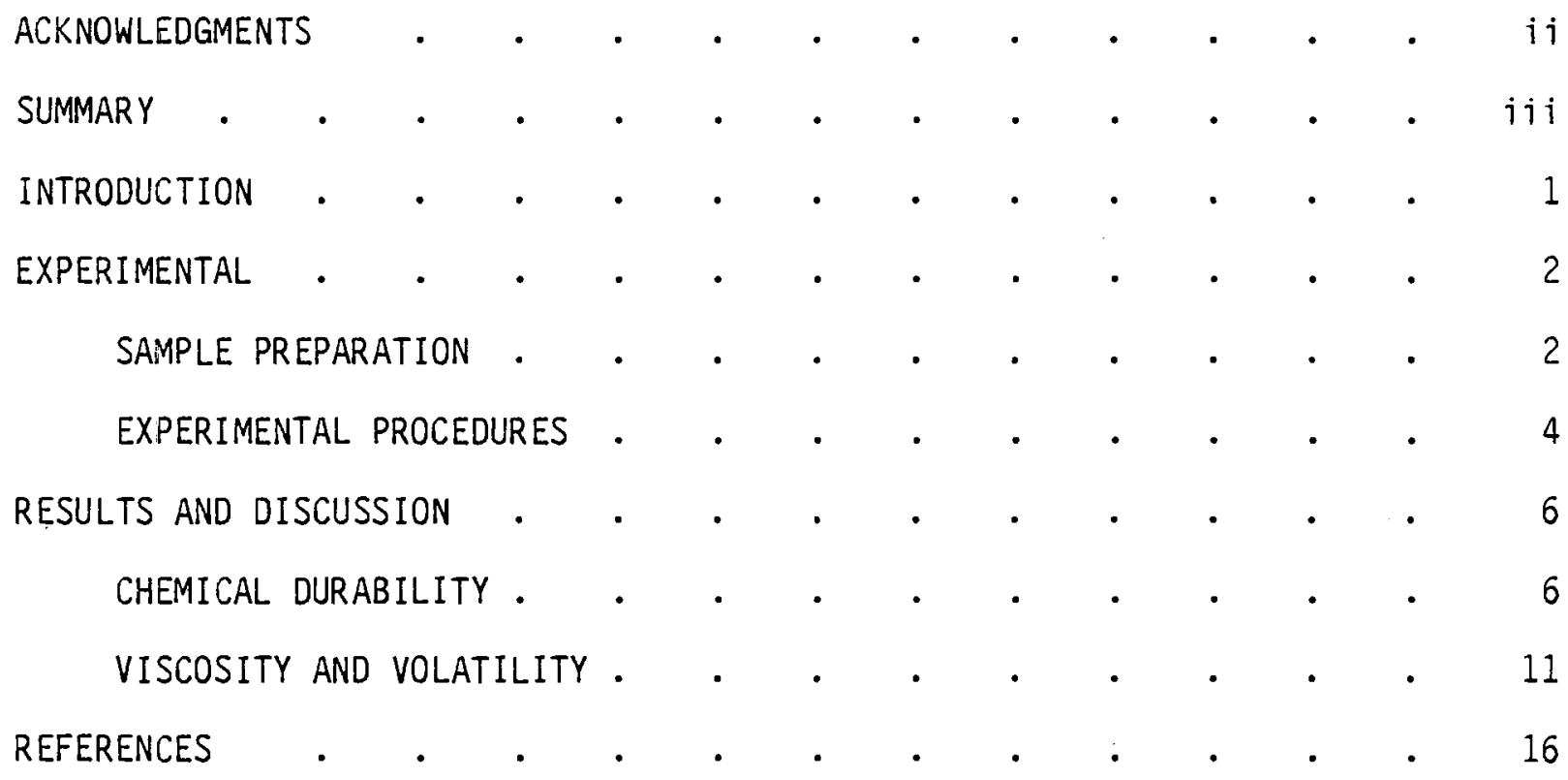




\section{FIGURES}

1 Cumulative Silicon Released Versus Time at $90^{\circ} \mathrm{C} \quad$. $\quad$. $\quad$. $\quad$ e 6

2 Cumulative Sodium Released Versus Time at $90^{\circ} \mathrm{C} \quad$. $\quad$. $\quad$. $\quad$. 8

3 Nine-Day Cumulative Silicon Release Versus Temperature • • • 9

4 Viscosity Versus Temperature . . . . . . . . . . . 13

5 Total Leaching Release Versus Melting Temperature . • • . $\quad 14$

6 Volatility Versus Temperature . . . . . . . . . . . 15

\section{TABLES}

1 Compositions of Test Glasses (mole\%), Melting Temperatures,

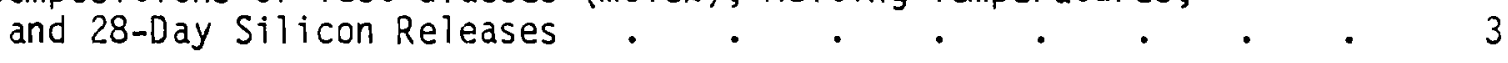

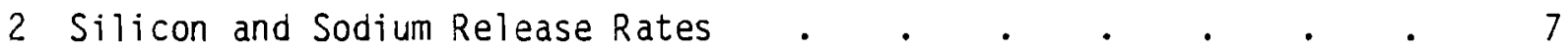




\section{INTRODUCTION}

Radioactive waste incorporated in glass is one of the major waste form options under investigation for immobilization of nuclear waste. Other alternatives include alumina-, silica- and titanate-based crystalline assemblages cement, and multibarrier waste forms. Perhaps the most important property of a nuclear waste form is its chemical durability since leaching and migration of radionuclides into repository ground waters and subsequently into the biosphere is the most credible transport scenario. This priority is indicated by proposed Nuclear Regulatory Commission (NRC) regulations for nuclear waste forms, (i) which place primary emphasis on control of the leach rate once the waste form reaches the repository.

Investigations of the chemical durability of a wide range of waste glass compositions have been progressing at Pacific Northwest Laboratory (PNL) (a) under sponsorship of the U.S. Department of Energy (DOE). The purpose of this report is to present data demonstrating that waste glasses can be formulated that are more durable than wel1-known reference waste glasses. Over 100 compositions have been investigated leading to an improved class of glasses. Data are presented on nine representative compositions in this report, including leaching results, viscosity, and volatility.

(a) Operated for DOE by Battelle Memorial Institute. 


\section{EXPERIMENTAL}

\section{SAMPLE PREPARATION}

The $g$ lass compositions included in this report are shown in Table 1. Glass 79-339 is a simplified base-glass composition that was found to have excellent chemical durability. Glass TDS $+79-339$ contains $28 \mathrm{wt} \%$ of a simulated Savannah River Laboratory (SRL) defense waste (TDS (a) waste) that was generated by the Purex process; it is similar to glass 79-339. Glass TDS/211 is an SRL reference glass containing 28 wt\% TDS waste. The RHO Purex glass was developed by Rockwell Hanford Operations (RHO) and contains 30 wt\% simulated Purex reprocessing Hanford defense waste. RHO also developed the RHO Residual Liquor glass, which contains $24 \mathrm{wt} \%$ of a potential sodium- and aluminum-rich Hanford defense waste.

The other four glasses are commercial power reactor waste glasses. Glass 76-68, a widely reported reference waste glass, contains 33 wt\% of a simulated power waste (PW-8a) rich in sodium and iron. The full composition of glass 76-68 is reported elsewhere. (2) Glass 77-260 was formulated to contain 33 wt\% of PW-7c--a power waste containing significant amounts of sodium, gadolinium, phosphorous, zirconium, and molybdenum. The full composition of 77-260 is also reported elsewhere. (3) Glasses $79-417$ and $79-418$ were patterned after glass 79-339 (Table 1) to establish that this nigh-durability base glass could contain simulated power wastes. Glass $79-417$ coniains 34 wt\% of simulated power waste PW-4b--a waste containing significant amounts of zirconium, molybdenum, ruthenium, cerium, and cesium. Glass $79-418$ contains 10 wt\% of PW-4b waste; the full composition of PW-4b is reported in Reference 2.

Samples were prepared by melting batches composed of oxides, nitrates, and carbonates in platinum crucibles in electric resistance-heated furnaces with air atmosphere. The melting temperatures used are listed in Table 1, and melting was carried out for 2 hours. Chemical durability tests utilized samples that were diamond-sawed from annealed bars poured from the melt into a steel bar mold. Volatility and viscosity tests were performed on remelted crushed glass.

(a) Technical Data Summary 
TABLE 1. Compositions of Test Glasses (mole\%), Melting Temperatures, and 28-Day Silicon Releases

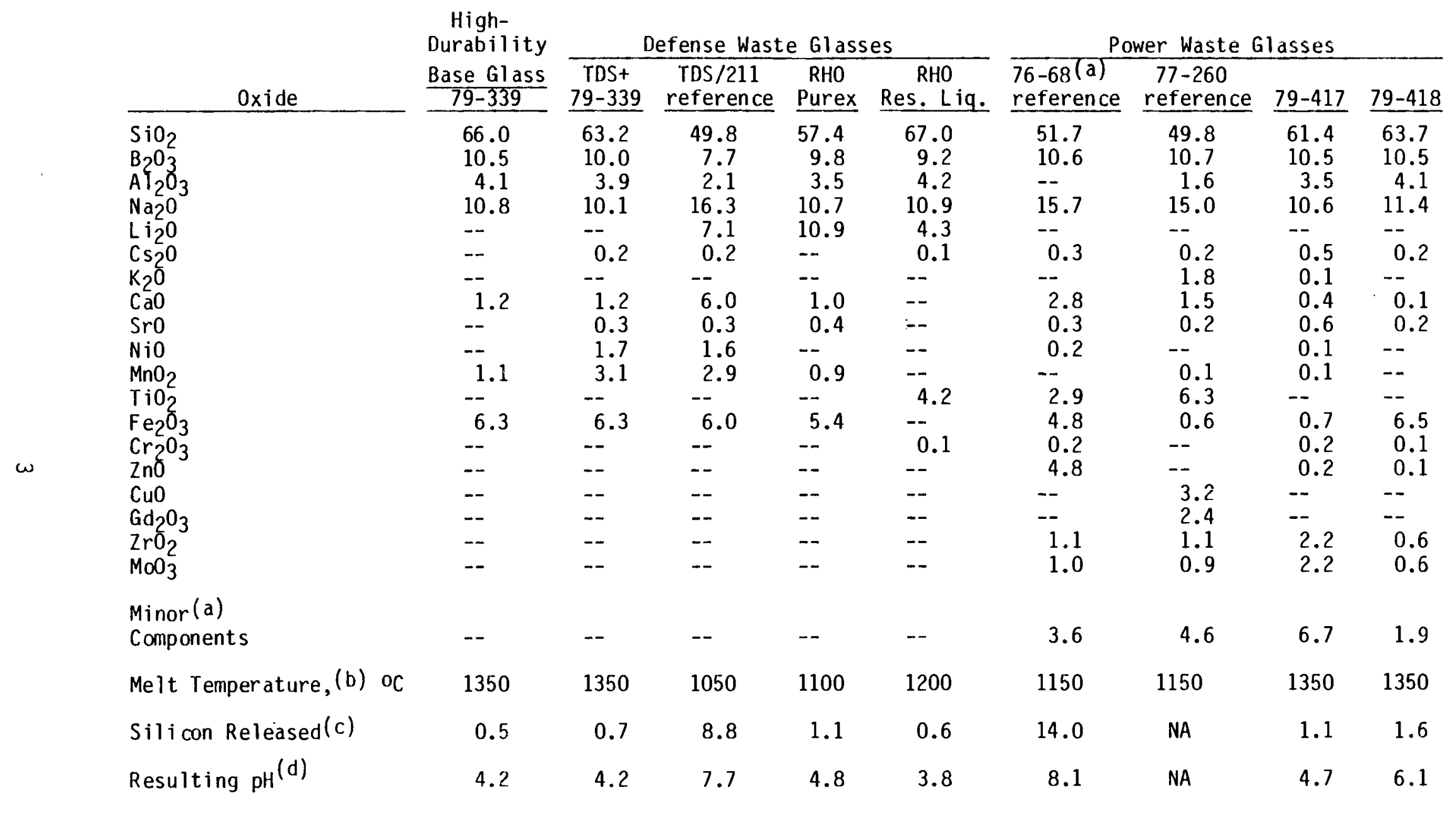

(a) Minor components each less than 1 molex.

(b) Temperature at which leach test samples were melted.

(c) Silicon released (normalized $\mathrm{g} / \mathrm{m}^{2}$ ) after 28 days, $90^{\circ} \mathrm{C}$ in deionized water leachant at $\mathrm{SA} / \mathrm{SV}=10 \mathrm{~m}-1$.

(d) Resulting $\mathrm{pH}$ measured in leachate after 28 days at $90^{\circ} \mathrm{C}$ at $\mathrm{SA} / \mathrm{SV}=10 \mathrm{~m}^{-1}$. Initial $\mathrm{pH}$ of deionized water leachant was 5.7 . 


\section{EXPERIMENTAL PROCEDURES}

Chemical durability was measured by two static tests in deionized water-one at $90^{\circ} \mathrm{C}$ and one at hydrothermal temperatures $\left(100\right.$ to $200^{\circ} \mathrm{C}$ ). In the $90^{\circ} \mathrm{C}$ test, blocks of glass were suspended in deionized water within sealed, polypropylene containers. The water volume was adjusted so that the geometric sample surface area to solution volume ratio (SA/SV) was $10 \mathrm{~m}^{-1}$, and the containers were $\mathrm{placed}$ in a $90^{\circ} \mathrm{C} \pm 1^{\circ} \mathrm{C}$ controlled-temperature bath without agitation. At the specified time, the container was pulled from the bath, the sample was removed, and the $\mathrm{pH}$ of the leachate was measured. The leachate was then analyzed chemically by inductively coupled plasma atomic emission spectroscopy (ICP).

The hydrothermal leaching tests were conducted in TFE Teflon ${ }^{\circledR}-1$ ined acid digestion bombs. Glass block samples were prepared as for the $90^{\circ} \mathrm{C}$ leach test and placed in the bombs with a measured amount of deionized water to maintain $S A / S V=6 \mathrm{~m}^{-1}$. The bombs were then sealed and $\mathrm{placed}$ in temperature-controlled ovens for 9 days at 100,150 , or $200^{\circ} \mathrm{C} \pm 5^{\circ} \mathrm{C}$. Water vapor pressures were $1 \mathrm{~atm}$ for the $100^{\circ} \mathrm{C}$ test and 4.7 and $15.3 \mathrm{~atm}$ for the 150 and $200^{\circ} \mathrm{C}$ tests, respectively. Upon removal from the ovens, the bombs were rapidly cooled by immersion in $\sim 20^{\circ} \mathrm{C}$ water, the lids were removed, and the leachate was pipetted out for ICP analysis.

Leaching results are presented in a unit appropriate for comparison of the chemical durability of nuclear waste forms. The normalized grams per square meter unit is independent of waste form specimen size, shape, and composition.

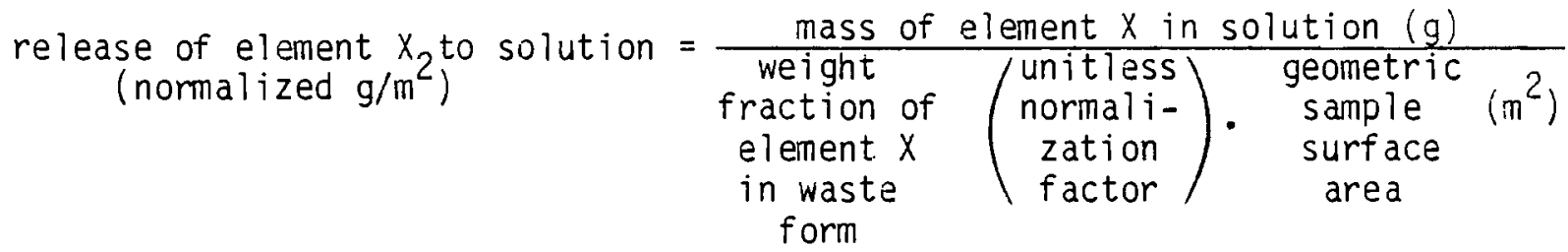

Registered trademark of E. I. du Pont de Nemours and Company, Inc., Wilmington, Delaware. 
Viscosity of the glass melis was tested using the rotating spindle method. The system was calibrated using National Bureau of Standards (NBS) standard glasses.

Volatility was determined by weight loss from $2-\mathrm{g}$ glass samples in platinum crucibles suspended in a $2-i n$. inside diameter (ID) vertical tube furnace for 3 hours with approximately 1 liter/min dry air flowing upward. The surface area of the glass sample was $2 \mathrm{~cm}^{2}$. 


\section{RESULTS AND DISCUSSION}

CHEMICAL DURABILITY

Since the major network former in the glasses is silicon, data on silicon release during leaching provide a good indication of relative durability. Figure 1 shows cumulative silicon release for the static test at $90^{\circ} \mathrm{C}$ in deionized water. After 28 days, releases for the high-durability glasses fall in a band that is roughly one order of magnitude less than releases for the two reference glasses (76-68 and TDS/211). Average leach rates based on the cumulative silicon release between 14 and 28 days also show about one order of magnitude difference between reference and high-durability glasses (see Table 2).

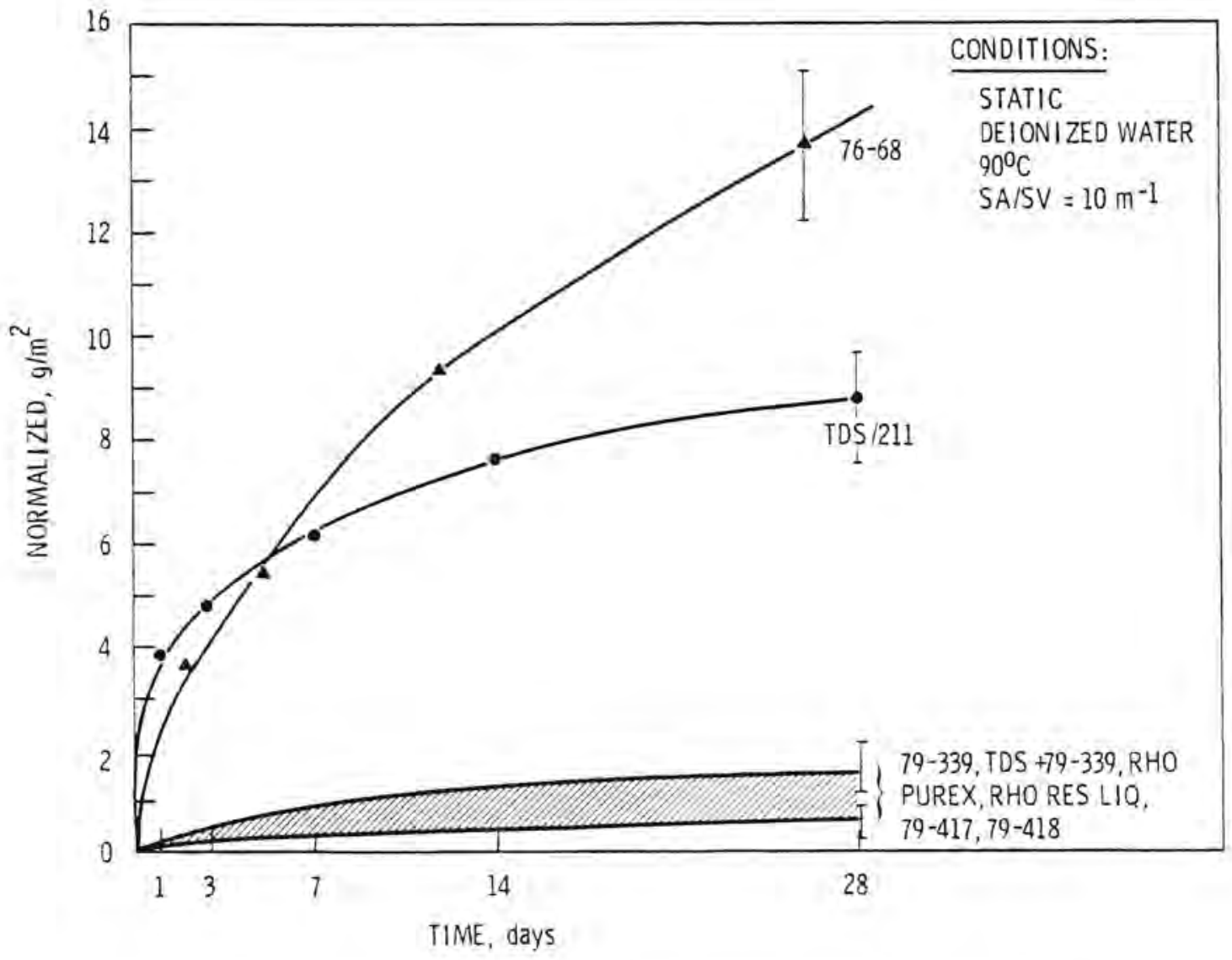

FIGURE 1. Cumulative Silicon Released Versus Time at $90^{\circ} \mathrm{C}$ 


\section{TABLE 2. Silicon and Sodium Release Rates}

\begin{tabular}{|c|c|c|c|}
\hline Glass & \multicolumn{2}{|c|}{$\begin{array}{c}\text { Silicon Release Rate, } \\
\text { normalized } \mathrm{g} / \mathrm{m}^{2}-\mathrm{d}\end{array}$} & $\begin{array}{c}\text { Sodium Release Rate, } \\
\text { normalized } \mathrm{g} / \mathrm{m}^{2}-\mathrm{d}\end{array}$ \\
\hline $76-68$ & \multicolumn{2}{|c|}{0.31} & 0.42 \\
\hline TOS/211 & \multicolumn{2}{|c|}{0.08} & 0.24 \\
\hline $79-339(a)$ & \multicolumn{2}{|c|}{0.01} & 0.03 \\
\hline $79-418^{(a)}$ & \multicolumn{2}{|c|}{0.03} & 0.09 \\
\hline & Conditions: & $\begin{array}{l}\text { Static } \\
\text { Deionized } \\
90^{\circ} \mathrm{C} \\
\mathrm{SA} / \mathrm{SV}=10 \\
\text { Avg rate f }\end{array}$ & 14 to 28 days \\
\hline
\end{tabular}

(a) Data are shown for the most durable (79-339) and the
least durable (79-418) of the six high-durability
glasses reported.

Alkali release is usually faster than silicon release from glasses because the alkalis are less strongly bound in the glass structure than silicon. Alkali mobility is a consequence of ion exchange with positively charged hydrogen species from the water. (4) Figure 2 shows sodium release versus time. Although these sodium release values are higher for all the glasses than the silica release values in Figure 1, the relationships between the glasses are very similar to those in Figure 1. For both the cumulative release after 28 days and for the 14-28 day release rates (Table 2) the high-durability glasses are about a factor of 10 better than the reference glasses.

Although the improved glasses are significantly more durable than the reference glasses at $90^{\circ} \mathrm{C}$, the differences diminish as the leachate temperature is increased. Figure 3 is an Arrhenius plot of silicon release versus reciprocal temperature for the static hydrothermal test at 9 days. Data for two reference glasses--TDS/211 and 77-260--are plotted along with data for a supercalcine ceramic and two high-durability glasses--79-339 and TDS+79-339. Data on the supercalcine and on glass 77-260 were collected in an earlier study. 


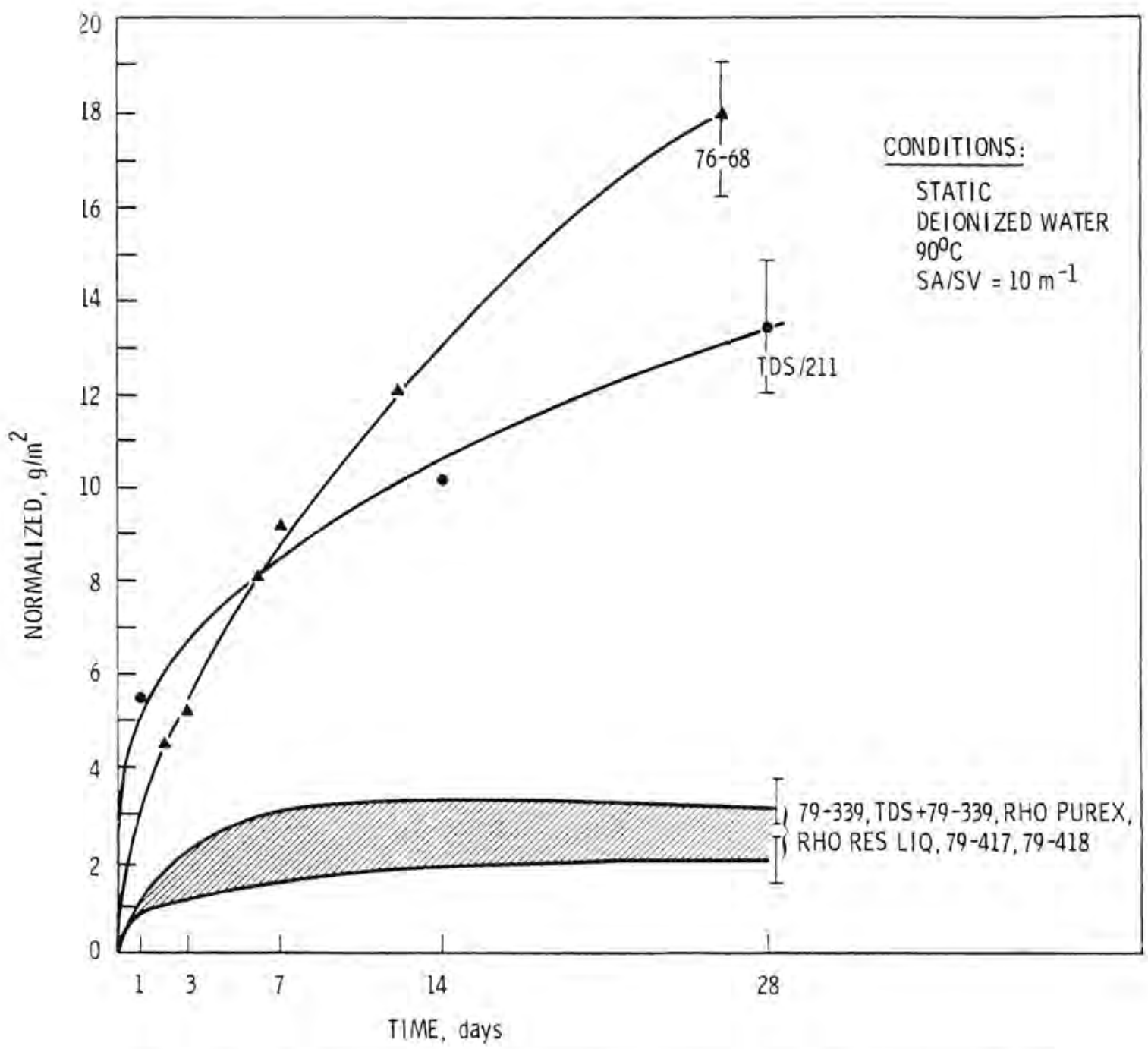

FIGURE 2. Cumulative Sodium Released Versus Time at $90^{\circ} \mathrm{C}$

As can be seen from the curves for TDS/211 and TDS+79-339 (glasses containing similar amounts of the same simulated TDS waste) there is a significant difference in silicon release at $100^{\circ} \mathrm{C}$; however, this difference diminishes to within experimental error at $200^{\circ} \mathrm{C}$. (Curvature in the lines on Figure 3 is utilized for clarity and should not be considered significant in view of the magnitude of error.) The advantage of the high-durability glasses tested thus far is limited to temperatures below about $150^{\circ} \mathrm{C}$. Figure 3 shows that the advantage increases greatly as the temperature declines. 


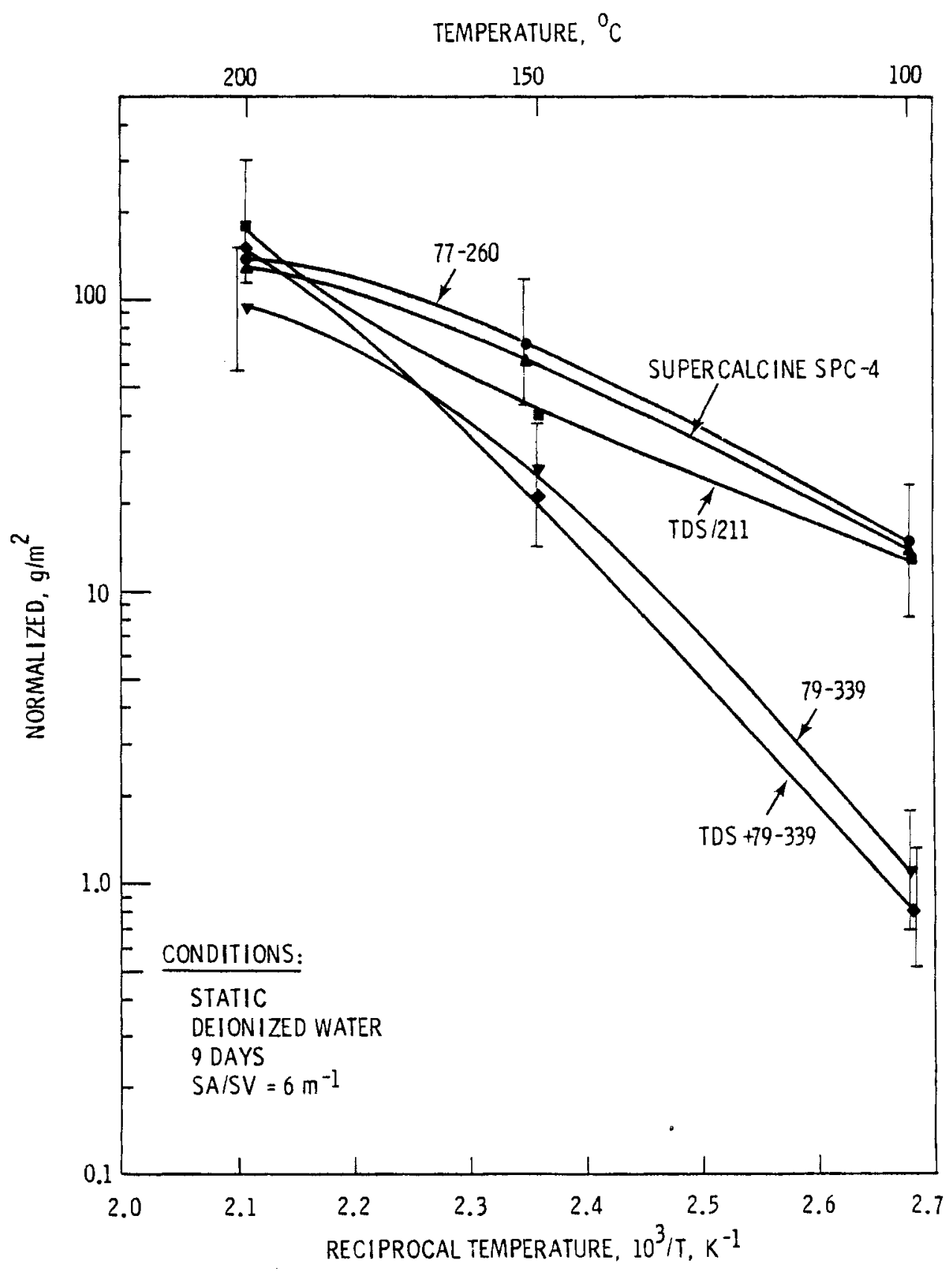

FIGURE 3. Nine-Day Cumulative Silicon Release Versus Temperature 
Research is in progress to investigate leaching mechanisms and to determine how glass compositions affect these mechanisms to produce the range of chemical durabilities shown in Figures $1-3$. The present studies of elemental release and resulting leachate $\mathrm{pH}$ tend to support the contention that there are two mechanisms of glass-water interaction: alkali ion exchange and hydroxyl attack of the matrix. $(4,6,7,8)$ Table 1 lists resulting leachate $\mathrm{pH}$ as well as silicon release after 28 days at $90^{\circ} \mathrm{C}$. Notice that those glasses that caused the leachate to become basic (TDS/211 and 76-68) released the larger amounts of silicon. We believe that these glasses are less durable because they are more susceptible to ion exchange. Alkali ions exchange with positively charged water species such as $\mathrm{H}_{3} \mathrm{O}^{+}$since isolated $\mathrm{H}^{+}$is probably rare in aqueous solutions. Removal of such species from the leachate causes the leachate $\mathrm{pH}$ to become basic. Electron sputtering for chemical analysis (ESCA) composition profiles of leached surfaces on those glasses that result in basic leachate $\mathrm{pH}$ show that alkali ions are depleted to greater depths than in those glasses that result in acid leachate $\mathrm{pH}$. Transport of ions such as $\mathrm{H}_{3} \mathrm{O}^{+}$into the glass could result in matrix attack by hydroxyl groups with a resultant enhanced gel layer formation and expanded lattice to enhance ionic mobilities. In this manner, susceptibility to ion exchange signified by basic leachate $\mathrm{pH}$ would result in faster dissolution of the glass and larger gel layer development.

The acidic leachate pHs observed with the more durable glasses may result from the presence of aluminum and iron and their proportions in relation to the total alkali content. Aluminum and iron readily react with $\mathrm{OH}^{-}$from the leachant to form hydroxides that are soluble only at very acidic $\mathrm{pHs.} \mathrm{Such} \mathrm{OH}^{-}$ absorption accounts for the acidic leachates. Addition of aluminum has been found to decrease alkali ion mobility in alkali silicate glasses. (9) Iron as well as aluminum may reduce alkali ion mobility in borosilicate glasses when they are introduced in proper proportion to alkali, thus decreasing the possibility for ion exchange. The result is a near-surface reaction with a thin gel layer due to the fact that ion exchange, which introduces water deeper into the glass, has been significantly inhibited. Thus, astute glass formulation protects the glass from ion exchange, which results in decreased dissolution. Apparently, the degree of protection from ion exchange is a function of 
temperature so that by $200^{\circ} \mathrm{C}$ (and maintaining a liquid phase) the large differences in dissolution rates between glasses observed at lower temperatures are diminished (see Figure 3 ).

Composition differences resulting in increased durability of the present glasses over reference glasses are more subtle than is implied by Table 1. Certainly, increased $\mathrm{SiO}_{2}$ content is important; notice in Table 1 that the high-durability glasses contain 6-18 mole\% more $\mathrm{SiO}_{2}$ than the reference glasses. Alkali content has some influence on durability, but there are exceptions. For example, the RHO Purex glass contains nearly as much alkaline oxides (21.6 mole\%) as the TDS/211 glass (23.6 mole\%); however, the former glass is a factor of eight more durable. Glass $79-339$ contains half as much alkaline oxides ( 10.8 mole\%) as the RHO Purex glass but is only a factor of two more durable. The beneficial effects on durability of $\mathrm{Al}_{2} \mathrm{O}_{3}$ and $\mathrm{Fe}_{2} \mathrm{O}_{3}$ and the detrimental effects of more than about $3 \mathrm{~mole} \% \mathrm{CaO}$ in these glasses are at least as important as the effects of total $\mathrm{SiO}_{2}$ and alkali contents. Although more work is needed to explain the causes of the improvement in durability, we conclude that waste glasses can be formulated to contain both defense and commercial power wastes that are significantly more durable at likely repository conditions than the widely reported reference waste glasses.

\section{VISCOSITY AND VOLATILITY}

The procedure for choosing optimum waste forms for immobilization of nuclear waste must involve tradeoffs between product properties and process feasibility. Although process demonstration for crystalline alternative waste forms is in the early stages, the technology for glass waste form production in the United States has advanced to the point of full-scale nonradioactive testing as well as pilot-scale and some full-scale testing with fully radioactive glasses. The important processing properties are melting temperature, volatility, refractory corrosion, and, for the case of joule-heated melting, electrical conductivity. In this report, melting temperature and volatility of the glasses of interest will be addressed.

For joule-heated melting, the glass must be heated until its viscosity is reduced to about 100 poise so that it will drain from the melter into the 
canister. Thus, the required meliing temperature of waste glasses can be defined as the temperature at which the viscosity of the glass reaches 100 poise. (10) Present state-of-the-art joule-heated melters for waste immobilization can be operated up to $\sim 1150^{\circ} \mathrm{C}$; the commercial glass industry, however, operates similar melters to much higher temperatures $\left(\sim 1450^{\circ} \mathrm{C}\right) .(10)$ Thus, waste glasses whose viscosity reaches 100 poise at or below $1150^{\circ} \mathrm{C}$ can be melted in current waste melters whereas higher melting waste glasses would require further melter development, drawing on nonnuclear commercial glass practice.

Viscosity curves for five of the glasses iisted in Table 1 are shown in Figure 4. It is apparent that the TDS+79-339 glass and the RHO Residual Liquor glass have melting temperatures well above the $1150^{\circ} \mathrm{C}$ limit for present waste glass joule-heated melters ( 1450 and $\sim 1330^{\circ} \mathrm{C}$, respectively). TDS/211 reaches 100 poise at $\sim 900^{\circ} \mathrm{C}$, which is well below the $1150^{\circ} \mathrm{C}$ limit. Glass 76-68 and RHO Purex glass reach 100 poise near $1100^{\circ} \mathrm{C}$; therefore, both of these glasses can be melted using present equipment. The comparably shallow slope of the RHO Purex glass viscosity curve is interesting; this relative insensitivity to temperature change is not presently understood.

In general, it can be expected that higher melting glasses will be more chemically durable than lower melting glasses. This follows from themodynamic considerations: that higher energy input will be required to dissolve the more stable glass structures that require higher energy for their formation. This rule of thumb is supported by data in Figure 5--a plot of melting temperature versus 28-day, $90^{\circ} \mathrm{C}$ dissolution for five glasses. As can be seen, the higher melting glasses generally lose the fewest elements. Two glasses--TDS/211 and RHO Purex--however, lie on the right side of the trend in Figure 4 and have better durability in relation to their melting temperature than do the other glasses.

Volatility of glass components during melting is of some concern to waste glass formulation since the off gas from waste glass melters must be trapped and purified or recycled. Figure 6 shows volatility curves for four glasses. A previous unpublished study showed that there is a negative correlation between viscosity and volatility; that is, for a given temperature, 


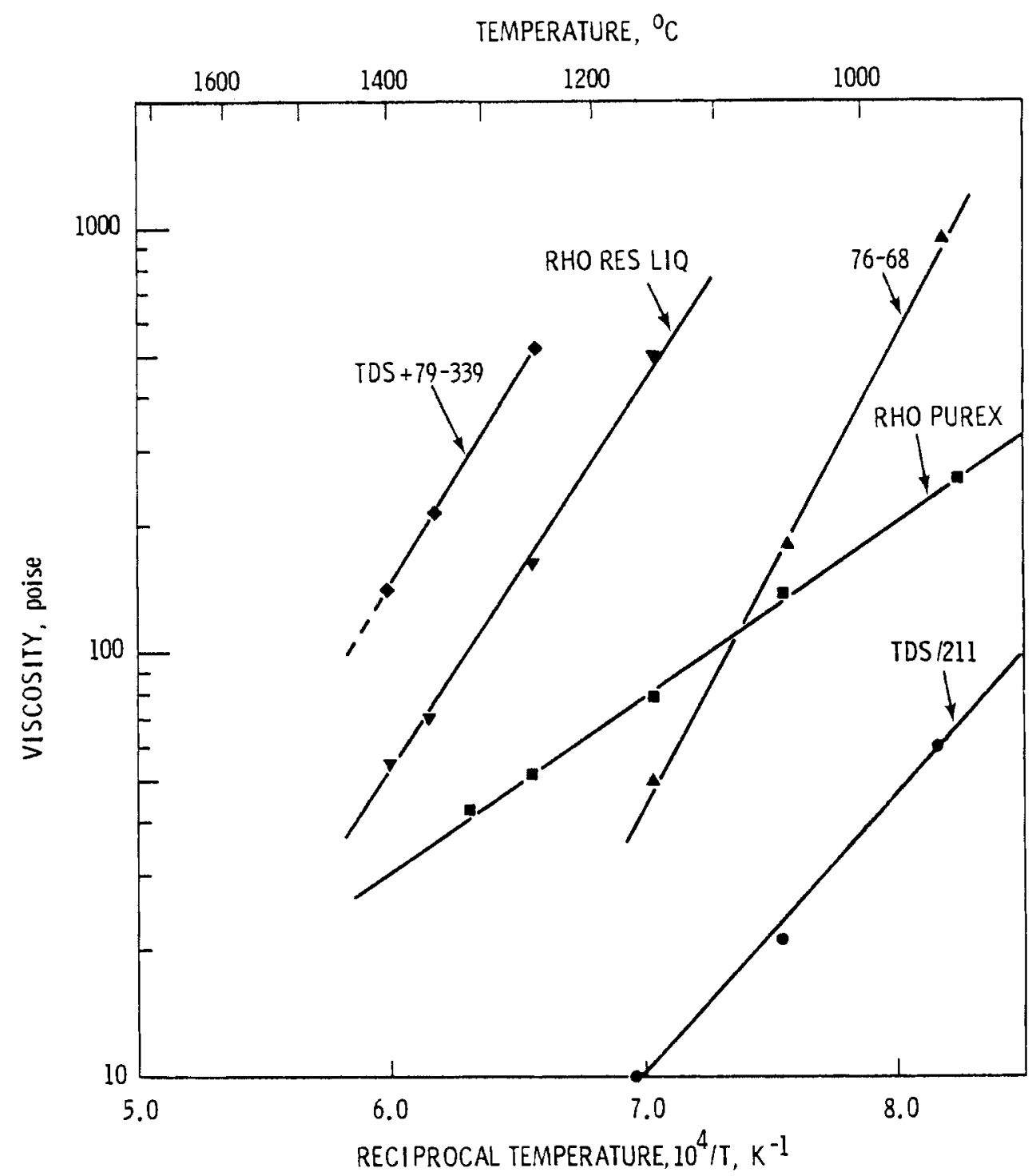

FIGURE 4. Viscosity Versus Temperature

high-viscosity glasses have low volatility. This is believed to occur because convection currents in the glass play an important role in replenishing the melt surface with volatile elements. High viscosity impedes convection and thus impedes volatility. However, the proper way to compare the volatility for engineering requirements is to examine volatility at the required melting temperatures. On that basis, the two higher melting glasses--79-339 and TDS+79339--have much higher volatility than the RHO Purex and TDS $/ 211$. At $1450^{\circ} \mathrm{C}$ (the approximate melting temperature of glasses 79-339 and TDS+79-339) these 


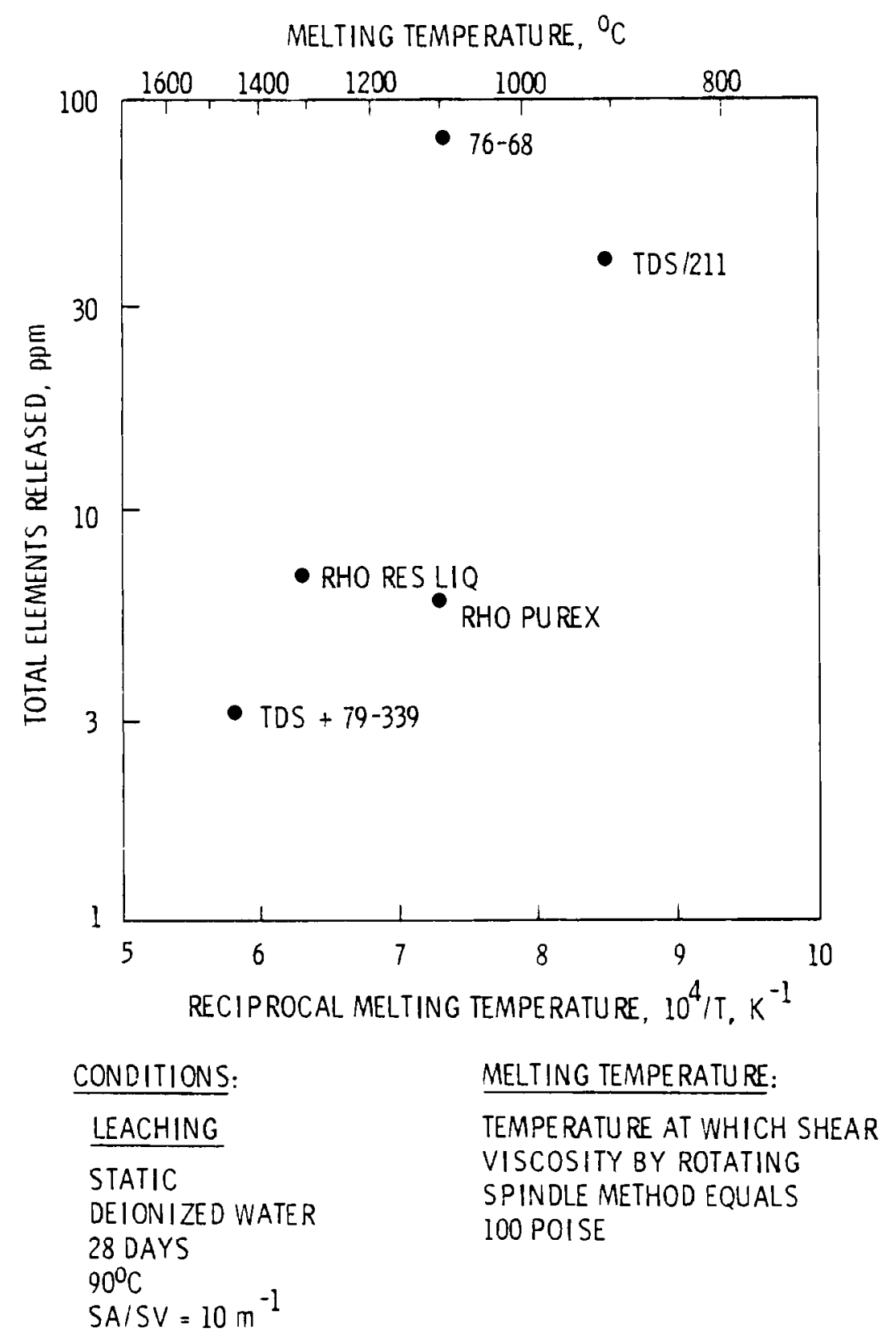

FIGURE 5. Total Leaching Release Versus Melting Temperature

glasses have volatilities near 100-mg loss. Data on RHO Purex glass must be extrapolated to estimate a volatility of $\sim 1-m g$ loss at its $1100^{\circ} \mathrm{C}$ melting temperature. To estimate the volatility of TDS/211 at $900^{\circ} \mathrm{C}$ would require an even more drastic extrapolation. However, in practice electrical conductivity requirements result in TDS $/ 211$ being melted at about $1050^{\circ} \mathrm{C}$ where its 


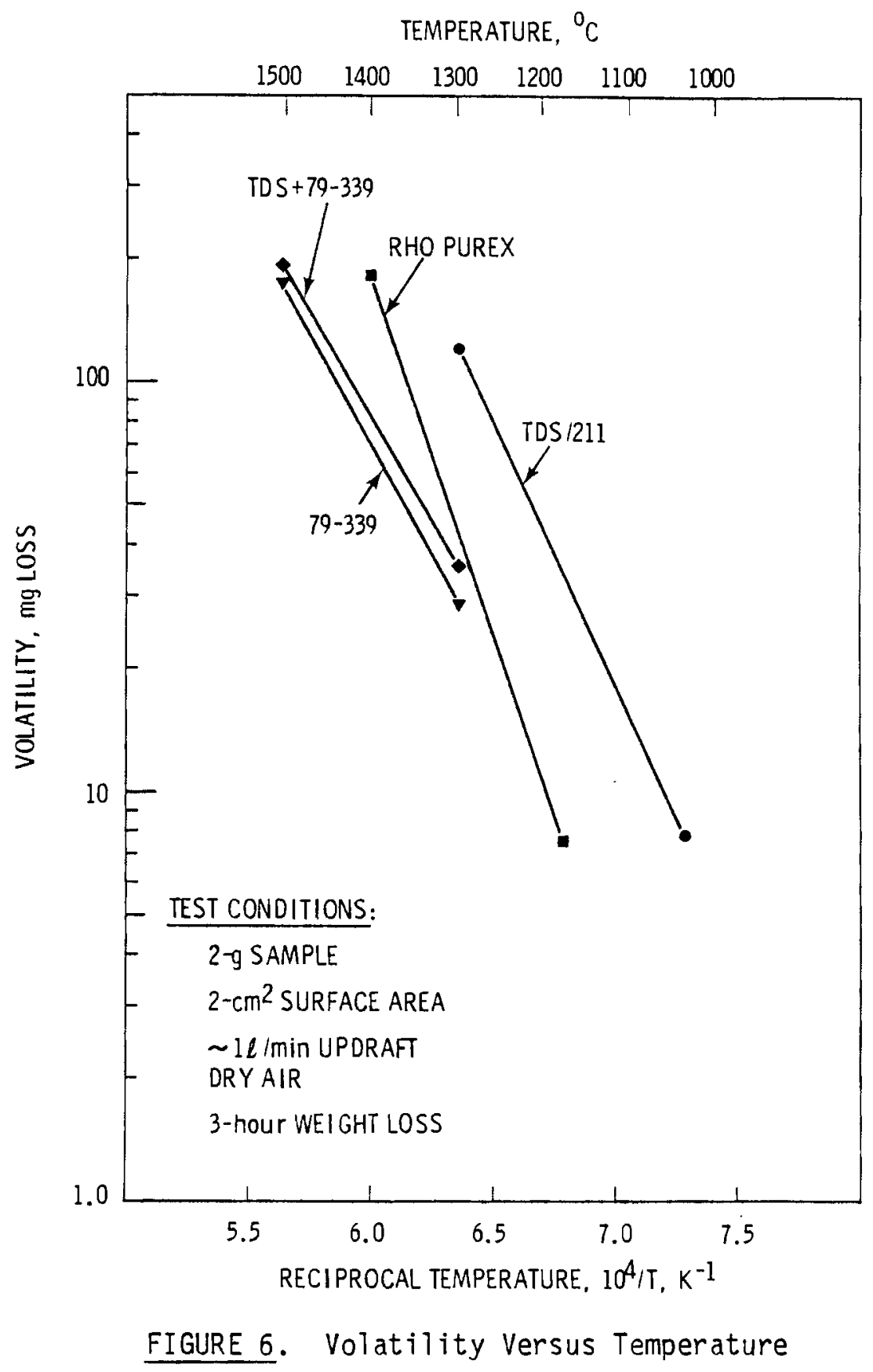

volatility is about $3-\mathrm{mg}$ loss. It is obvious then that the higher melting glasses will volatilize at much higher rates than the current reference glass TDS/211 or the RHO Purex glass. However, increased volatility may be reasonably compensated for by keeping a thick "cold cap" of unmelted batch over the melt to act as a reflux or by increasing the capacity of the off-gas system. 


\section{REFERENCES}

1. U.S. Nuclear Regulatory Commission, Title 10, Code of Federal Regulations, Part 60, Appendix II (10CFR60), Advance Notice of Proposed Rulemaking.

2. Mendel, J. E., et al. 1977. Annual Report on the Characteristics of High-Level Waste Giasses. BNWL-2252, Pacific Northwest Laboratory, Richland, Washington.

3. MCElroy, J. L. May 1979. Quarterly Progress Reports - Research and Development Activities - High-Level Waste Immobilization Program: January-December 1978. PNL-2999-1,2,3,4, Pacific Northwest Laboratory, Richland, Washington.

4. Das, C. R. 1969. "Theoretical Aspects of the Corrosion of Glass." The Glass Industry 50:422-427.

5. Westsik, J. H., Jr., J. W. Shade, and G. L. McVay. 1979. "Temperature Dependence of Hydrothermal Reactions in Waste Glasses and Ceramics." In Scientific Basis for Nuclear Waste Management, Vol. 2, Plenum Press, New York.

6. Clark, D. W., et al. 1976. "Aqueous Corrosion of Soda Silica and SodaLime Silica Glass." J. American Ceramic Society 59(1):2.

7. Doremus, R. H. August 1968. "Exchange and Diffusion of Sodium and Silver Ions in Pyrex Glass." Physics and Chemistry of Glasses 9:128.

8. Clark, D. W., C. J. Pantano, and L. L. Hench. 1979. Corrosion of Glass. Magazines for Industry, New York.

9. McVay, G. L., and D. E. Day. 1970. "Diffusion and Internal Friction in Single-Alkali Glasses." J. American Ceramic Society 53(5).

10. Stanek, J. 1977. Electric Melting of Glasses. Elsevier Scientific Publishing Company, New York. 


\section{DISTRIBUTION}

No. of

Copies

OFFSITE

A. A. Churm

DOE Patent Division

9800 S. Cass Avenue

Argonne, IL 60439

13 DOE Nuclear Waste Management

Programs

NE30, B-107, HQ

Washington, DC 20545

ATTN: C. R. Cooley

G. H. Daly

J. E. Dieckhoner

C. H. George

C. A. Heath

M. L. Lawrence

D. J. McGoff

S. Meyers/R. Romatowski

G. Oerte]

A. F. Perge

R. W. Ramsey, Jr.

D. L. Vieth

R. D. Walton

R. E. Cunningham

Office of Nuclear Safety

Materials and Safeguards

Room 562

Nuclear Regulatory Commission 7915 Eastern Avenue

Silver Springs, MD 20910

3 Division of Waste Management Nuclear Regulatory Commission Washington, OC 20555

ATTN: J. B. Martin

D. M. Rohrer

R. Dale Smith

W. E. Mott

DOE Division of Environmental Control Technology Washington, DC 20545
No. of

Copies

S. A. Mann

DOE Chicago Operations and Region Office

Argonne, IL 60439

J. Neff

DOE Columbus Program Office

$505 \mathrm{King}$ Avenue

Columbus, $\mathrm{OH} 43201$

4 DOE Idaho Operations Office

550 2nd St.

Idaho Falls, ID 83401

ATTN: K. A. Carlson

J. P. Hamric

J. W. Peel

J. B. Whitsett

2 DOE Oak Ridge Operations Office

P.0. Box E

Oak Ridge, TN 37830

ATTN: S. W. Ahrends

D. Large

3 DOE Savannah River Operations Office

P.0. Box A

Aiken, SC 29801

ATTN: E. S. Goldberg

T. B. Hindman

R. P. Whitfield

S. G. Harbinson

DOE San Francisco Operations

1333 Broadway

0akl and, CA 94612

2 DOE ATbuquerque Operations Office

P.0. Box 5400

Albuquerque, NM 87185

ATTN: R. Y. Lowrey

A. L. Taboas 
No. of

Copies

27 DOE Technical Information Center

Oak Ridge National Laboratory

ATTN: R. E. Blanco

P.0. BoX Y

Oak Ridge, TN 37830

Los Alamos Scientific Laboratory

P.O. Box 1663

Los Alamos, NM 87544

Exxon Nuclear Idaho

ATTN: G. L. Ritter

P.0. Box 2800

Idaho Falls, ID 83401

Allied-General Nuclear Services

P.0. Box 847

Barnwell, SC 29812

ATTN: J. A. Buckham

2 Argonne National Laboratory

9700 South Cass Avenue

Argonne, IL 60439

ATTN: J. H. Kittel

M. J. Steindler/

L. E. Trevorrow

3 Battelle Memorial Institute

Office of Nuclear Waste Isolation

505 King Avenue

Columbus, $\mathrm{OH} 43201$

ATTN: A. Brandstetter

N. E. Carter

Beverly Rawles

3 Rockwell International

Rocky Flats Plant

P.0. Box 464

Golden, CO 80401

ATTN: W. S. Bennett

Lawrence J. Smith

E. Vejvoda
No. of

Copies

A. B. Martin

Rockwell International

8900 DeSoto Avenue

Canoga Park, CA 91304

8 E. I. du Pont de Nemours Co.

Savannah River Laboratory

Aiken, SC 29801

ATTN: M. D. Boersma

J. L. Crandall

R. G. Garvin

D. E. Gordon

J. A. Kelley

G. Wicks

A. S. Jennings

M. J. Plodinec

R. Williams

Electric Power Research Institute

3412 Hillview Avenue

P.0. Box 10412

Palo Alto, CA 94304

Environmental Protection Agency

Technological Assessment

Division (AW-559)

Office of Radiation Programs

U.S. Environmental Protection Agency

Washington, DC 20460

C. J. Kershner

Monsanto Research Corporation

Mound Laboratory

P.0. Box 32

Miamisburg, $\mathrm{OH} 45342$

J. P. Duckworth

Plant Manager

Nuclear Fuels Services, Inc.

P.0. Box 124

West Valley, NY 14171 
No. of

Copies

J. D. Tewhey

Lawrence Livermore Laboratory

P.0. Box 808

Livermore, CA 94550

3 Sandia Laboratories

Albuquerque, NM 87185

ATTN: D. R. Anderson

0 . E. Jones

R. G. Kepler

J. W. Bartlett

The Analytical Sciences Corp.

6 Jacob Way

Reading, MA 01867

R. G. Post

College of Engineering

University of Arizona

Tucson, $A Z 85721$

L. L. Hench

Dept. Of Materials Science and Engineering

University of Florida

Gainesville, FL 32611

H. Palmour, III

2140 Burlington Engineering Laboratories

North Carolina State University

Raleigh, NC 27607

W. Tope

Westinghouse Electric

Corporation

Penn Center, Bldg. 2

Box 355

Pittsburgh, PA 15230

R. Roy

202 Materials Research Laboratory

University Park, PA 16802
No. of

Copies

John Pomeroy

Technical Secretary

National Academy of Sciences

Committee of Radioactive Waste Management

National Research Council

2101 Constitution Avenue

Washington, DC 20418

J. R. Berreth

Allied Chemical Corporation

550 Second Street

Idaho Falls, ID 83401

Rod Ewing

University of New Mexico

Albuquerque, NM 87131

D. J. Hotaling

Penberthy Electromelt

International, Inc.

631 South 96 Street

Seattle, WA 98108

L. Penberthy

Penberthy Electromelt

International, Inc.

631 South 96 Street

Seattle, WA 98108

ONSITE

8 DOE Richland Operations Office

E. A. Bracken

P. A. Craig

O. J. Elgert

R. E. Gerton

H. E. Ransom

J. J. Schreiber

M. W. Shupe

M. J. Zamorski 
No. of

Copies

8 Rockwell Hanford Operations

L. C. Brown

R. A. Deju

D. R. Gustavson

B. A. Higley

M. J. Kupfer

I. E. Reep

D. D. Wodrich

United Nuclear Industries

T. E. Dabrowski

Westinghouse Hanford Company

A. G. Blasewitz

50 Pacific Northwest Laboratory

W. J. Bjorklund

H. T. Blair

W. F. Bonner

C. Q. Suckwalter (5)

L. A. Chick (12)
No. of

Copies

T. D. Chikalla

S. K. Edler

W. J. Gray

C. R. Hann

M. S. Hanson

O. F. Hill

J. H. Jarrett

D. E. Knowlton

L. T. Lakey

D. E. Larson

R. P. Marshall

J. L. McElroy

G. L. McVay

G. B. Mellinger

J. E. Mende 1

R. D. Nelson

R. E. Nightingale

C. R. Palmer

A. M. Platt

W. A. Ross

J. M. Rusin

R. J. Serne

R. P. Turcotte

Technical Information (5)

Publishing Coordination Fe(2) 